\title{
THE EFFECT OF COMBINATION OF MARMET TECHNIQUES AND WARM COMPRESSES ON PRODUCTION ASI IN POSTPARTUM MOTHER IN INDEPENDENT MIDWIFE PRACTICE DINCE SAFRINA PEKANBARU CITY
}

\author{
Lela Merlin', Lailiyana², Juraida Roito Harahap² \\ PMB Dince Safrina', Dosen Jurusan Kebidanan Poltekkes Kemenkes Riau² \\ Email Lelamerlin6@gmail.com
}

Article Info
Article history
Received date:
Revised date:
Accepted date:

\begin{abstract}
Breastfeeding problems that can arise from the first day to the third day postpartum is ASI not streamlined. ASI does not streamlined make the mother unable to meet the needs of the baby. The purpose of this study was to determine the effect of a combination of the technique marmet and warm compresses on milk production. The study was conducted in August 2019 until April 2020 in PMB Dince Safrina City of Pekanbaru. This type of research is quantitative research using a Quasi Experiment design. The population in this study were all postpartum mothers in January-February 2020 who delivered at PMB Dince Safrina totaling 27 people. The sample in this study were 20 postpartum mothers taken with incidental sampling technique. Data collection uses the observation method using an observation sheet. Data analysis used independent $t$ test with a significance level of $95 \%$. The results showed that the average milk production in the combination intervention group was $107.00 \mathrm{ml}$ (SD 22.63) compared to the marmet technical intervention group which was $77.00 \mathrm{ml}$ (SD 27.10). The conclusion of the study is the influence of the technique of marmet with and without warm compresses on milk production in postpartum mothers $(p=0,015)$, it intended the combination of marmet technique and warm compresses is more effective in increasing milk production. The advice given is that a combination of the marmet technique and warm compresses can be applied in midwifery care for postpartum mothers to help increase and expedite milk production.

Keywords:

ASI Production, Marmet Technique, Warm Compress
\end{abstract}

\begin{abstract}
Abstrak
Masalah menyusui yang dapat timbul pada hari pertama sampai hari ketiga postpartum adalah ASI tidak lancar.ASI tidak lancar membuat ibu tidak mampu memenuhi kebutuhan bayi.Tujuan penelitian ini adalah untuk mengetahui pengaruh kombinasi teknik marmet dan kompres hangat terhadapat produksi ASI.Penelitian dilaksanakan pada bulan Agustus 2019 sampai dengan April 2020 di PMB Dince Safrina Kota Pekanbaru.Jenis penelitian ini adalah penelitian kuantitatif menggunakan desain Quasi Eksperimen.Populasi pada penelitian ini adalah seluruh ibu postpartum bulan Januari-Februari 2020 yang bersalin di PMB Dince Safrina berjumlah 27 orang.Sampel pada penelitian ini adalah 20 ibu postpartum diambil dengan teknik Incidental sampling.Pengumpulan data menggunakan metode observasi menggunakan lembar observasi.Analisis data menggunakan uji $t$ independen dengan taraf signifikansi $95 \%$. Hasil penelitian didapatkan bahwa rata-rata produksi ASI pada kelompok intervensi kombinasi lebih banyak yaitu $107.00 \mathrm{ml}$ (SD 22.63) dibandingkan dengan kelompok intervensi teknik marmet yaitu $77.00 \mathrm{ml}$ (SD 27.10). Kesimpulan penelitian ada pengaruh teknik marmet dengan dan tanpa kompres hangat terhadap produksi ASI pada ibu postpartum $(p=0,015)$, yaitu kombinasi teknik marmet dan kompres hangat lebih efektif meningkatkan produksi ASI. Saran yang diberikan adalah
\end{abstract}


kombinasi teknik marmet dan kompres hangat dapat diterapkan dalam asuhan kebidanan pada ibu postpartum untuk membantu meningkatkan dan melancarkan produksi ASI.

Kata Kunci

Produksi ASI, Teknik Marmet, Kompres hangat

\section{PENDAHULUAN}

Air Susu Ibu (ASI) merupakan komponen terpenting yang produksi dan kelancarannya perlu diperhatikan oleh calon ibu yang mau menyusui bayinya. ASI merupakan cairan sekresi yang dihasilkan dari kelenjar payudara yang mengandung kolostrum yang kaya akan antibodi berfungsi sebagai daya tahan tubuh dan pembunuh kuman dalam jumlah tinggi. World Health Organization (WHO) membuktikan bahwa pemberian ASI sampai usia 2 tahun dapat menurunkan angka kematian anak akibat penyakit diare dan infeksi saluran napas akut, kasus pneumonia, obesitas, serta sindrom kematian bayi mendadak (SIDS)[1][2].

Menurut World Health Organization (WHO) tahun 2016, cakupan ASI eksklusif di seluruh dunia hanya $38 \%$ selama periode 2007-2014[3]. Indonesia menduduki peringkat ke-3 terbawah dari 51 Negara di dunia yang memberikan ASI eksklusif[4]. Secara nasional, cakupan bayi mendapat ASI eksklusif sebesar 61,33\%. Sedangkan Provinsi Riau cakupan bayi mendapatkan ASI eksklusif 57,65\% dari $80 \%$ target nasional[5]. Berdasarkan data Dinkes Kota Pekanbaru (2017) dari 20 Puskesmas yang ada di Kota Pekanbaru cakupan ASI eksklusif nomor 3 terendah adalah wilayah Puskesmas Rumbai Pesisir yaitu sebesar $42,67 \%$ dan diwilayah kerja Puskesmas Rumbai Pesisir angka kematian neonatal pada tahun 2017 tertinggi se Kota Pekanbaru yaitu 13,51\% kematian neonatal yang terjadi[6].

Faktor yang menyebabkan kegagalan dalam proses menyusui sering disebabkan oleh ibu yang mengeluh dalam pemberian ASI yaitu pengeluaran ASI yang tidak lancar[7]. Sekitar35\% lbu menghentikan pemberian ASI dengan alasan terbanyak adalah ASInya tidak lancar sehingga tidak dapat memenuhi kebutuhan bayinya [8].
Penurunan produksi dan kelancaran ASI pada hari pertama setelah melahirkan dapat disebabkan oleh kurangnya rangsangan hormon prolaktin dan oksitosin yang sangat berperan dalam kelancaran produksi dan pengeluaran ASI yang dipengaruhi oleh perasaan stress, gelisah, kurang percaya diri, takut, cemas, nyeri terus menerus[9]. Berdasarkan pengalaman penulis selama praktik di lapangan, ibu postpartum mengeluh hari ke 1-3 setelah melahirkan ASI tidak lancar sehingga kesulitan untuk menyusui bayinya, karena khawatir dengan bayinya ibu memberi bayinya susu formula sampai ASI ibu lancar.

Berbagai upaya yang dapat dilakukan untuk memperlancardan memperbanyak produksi ASI yang dapat digunakan untuk membantu ibu pasca melahirkan diantaranya yaitu metode perawatan payudara, pijat oksitosin, pijat punggung, teknik marmet, kompres hangat dan banyak upaya pemijatan lainnya. Upaya teknik marmet sangat efektif dilakukan untuk meningkatkan produksi dan melancarkan ASI, mengosongkan payudara yang penuh, mengurangi bengka atau sumbatan pada aliran ASI, mencegah puting dan aerola menjadi kering dan lecet, refleks keluarnya ASI lebih mudah terstimulasi dengan skin to skin contact, portable, ekonomis dan ibu dapat melakukannya sendiri. Sedangkan kompres hangat dapat memperlancar ASI karena dengan kompres ini akanmeningkatkan suhu payudara sehingga terjadinya vasodilatasi atau pelebaran pembuluh darah. Adanya vasodilatasi mengakibatkan peningkatan sirkulasi atau peredaran darah yang dapat menimbulkan relaksasi pada payudara.

Penelitian tentang pengaruh teknik marmet terhadap produksi ASI pada ibu postpartum yang dilakukan oleh Puspita, 
dkk (2019) Hasil analisa data sebelum dilakukan teknik marmet nilai mean 0,000 dan sesudah dilakukan teknik marmet nilai mean 0,57 , diperoleh nilai signifancy $=$ 0,001 ( $p$ value $<0,05$ ) yang berarti ada Pengaruh teknik marmet terhadap kelancara ASI pada ibu postpartum[10]. Dahlan dalam penelitiannya yang berjudul pengaruh teknik marmet terhadap kelancaran ASI pada ibu menyusui (2017) diberikan perlakuan diperoleh kelancaran ASI yang kurang sebanyak 8 orang $(33,3 \%)$ dan kelancaran ASI yang cukup sebanyak 16 orang $(66,7 \%)(\rho$-Value $=$ $0,027<0,05)[11]$.

Selain teknik marmet, untuk meningkatkan dan memperlancar produksi ASI juga menggunakan kompres hangat.Berdasarkan analisis deskriptif penelitian yang dilakukan oleh Nurhanifah (2013)dapat dijelaskan bahwa rata-rata kelancaran produksi ASI responden yang dilakukan kompres hangat pada pre intervensi adalah sebesar 2, 31 dan pada post intervensi sebesar 3, 06. Didapatkan hasil nilai signifikansi kurang dari á $=0,05$ $(0,002<0,05)$ sehingga dapat disimpulkan $\mathrm{HO}$ ditolak. Hal ini terlihat bahwa kelancaran produksi ASI pada post intervensi lebih tinggi dari pada pre intervensi[12].

Wilayah kerja Puskesmas Rumbai Pesisir terdapat Lima Praktek Mandiri Bidan.Salah satunya adalah PMB Dince Safrina. Hasil studi pendahuluan yang dilakukan peneliti di PMB Dince Safrina dengan

melakukan wawancara dengan pegawai PMB didapatkan data dari 55 ibu postpartum (data Juni-Agustus 2019) bahwa 56,3\% diantaranya mengeluh ASlnya keluar sedikit dan tidak lancar pada hari ke 1-3 setelah melahirkan sehingga pada hari ke-4 dan seterusnya produksi ASI tidak lancar dan banyak ibu yang memberikan susu formula demi memenuhi kebutuhan bayinya, sehingga peneliti tertarik melakukan penelitian untuk mengetahui "Pengaruh Kombinasi Teknik Marmet Dan Kompres Hangat Terhadap
Produksi ASI Pada lbu Postpartum di PMB Dince Safrina".

\section{METODE}

Penelitian ini merupakan penelitian kuantitatif dengan Jenis penelitian Quasy Eksperiment. Populasi penelitian ini adalah seluruh ibu postpartumhari pertama sampai hari ketiga di PMB Dince Safrina Kota Pekanbaru dengan sampel sebanyak 10 responden kelompok kombinasi teknik marmet dan kompres hangat dan 10 responden kelompok teknik marmet yang diambil dengan teknik Incidental Sampling. Metode pengumpulan data menggunakan lembar observasi dengan instrument penelitian berupa lembar observasi.Pengolahan dan analisis menggunakan metode komputerisasi (SPSS).Analisa data menggunakan Uji $T$ Independent pada derajat kepercayaan $95 \%$.

\section{HASIL DAN PEMBAHASAN}

Pada bab ini akan dipaparkan hasil penelitian yang sudah dilakukan tentang "Pengaruh Kombinasi Teknik Marmet dan Kompres Hangat Terhadap Produksi ASI Pada lbu Postpartum di PMB Dince Safrina Kota Pekanbaru" pada bulan Januari sampai dengan Maret 2020. Penelitian ini dilakukan pada 20 ibu postpartumyang dibagi menjadi 2 kelompok intervensi yang terdiri dari 10 kelompok intervensi yang dilakukan kombinasi teknik marmet dan kompres hangat dan 10 kelompok intervensi yang dilakukan teknik marmet. Hasil penelitian dapat dilihat pada tabel dibawah ini.

Tabel 1.Pengaruh Teknik Marmet dengan dan Tanpa Kompres Hangat terhadap Produksi ASI Pada Ibu Postpartum Di PMB Dince Safrina

\begin{tabular}{cccccc}
\hline Variabel $N \quad$ Mean $\quad S D$ & $\begin{array}{l}\mathrm{T}(t- \\
\text { tes) }\end{array}$ & $\begin{array}{c}P \\
\text { value }\end{array}$ \\
\hline
\end{tabular}




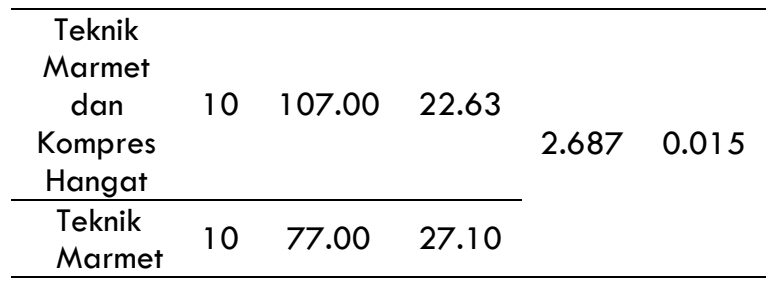

Pada tabel 5.1 dapat dilihat bahwa ratarata produksi ASI pada hari ke-4 pada kelompok intervensi kombinasi teknik marmet dan kompres hangat lebih tinggi dibanding kelompok intervensi teknik marmet saja yaitu $107.00 \mathrm{ml}$ (SD 22.63) dan pada kelompok intervensi teknik marmet $77.00 \mathrm{ml}$ (SD27.10). Hasil uji statistik $t$ independent pada derajat kepercayaan 95\%didapatkan bahwa ada perbedaan produksi ASI antara intervensi kombinasi teknik marmet dan kompres hangat dengan intervensi teknik marmet saja terhadap produksi ASI pada ibu postpartum ( $p=0,015)$.

\section{PEMBAHASAN}

Pada tabel 5.1 diatas hasil penelitian menunjukkan bahwa pada kelompok intervensi kombinasi teknik marmet dan kompres hangat produksi ASI pada ibu postpartum rata-rata $107.00 \mathrm{ml}$ sedangkan pada kelompok intervensi teknik marmet rata-rata produksi ASI adalah $77.00 \mathrm{ml}$. Dari nilai rata-rata tersebut terlihat bahwa produksi ASI pada ibu postpartum yang dilakukan intervensi kombinasi teknik marmet dan kompres hangat lebih tinggi dari pada ibu postpartum yang dilakukan intervensi teknik marmet. Hasil uji $t$ independen menunjukkan ada pengaruh kombinasi teknik marmet dan kompres hangat terhadap produksi ASI pada ibu postpartum ( $p=0,015)$.

Pada umumnya pada hari pertama sampai hari ketiga postpartum ibu merasa ASInya tidak lancar karena pada masa ini masih ada hormon kehamilan yaitu hormon progesterone, estrogen, HPL (Human Placental Lactogen) dan PIH (Prolactin Inhibiting Factor) sehingga menekan ASI untuk keluar yang disebut dengan fase laktogenesis II[7][2]. Produksi ASI akan meningkat setelah lebih dari tiga hari postpartum yang disebut laktogenesis III[13]. Produksi ASI yang kurang pada awal postpartum merupakan hal yang alamiah namun rangsangan hormon prolaktin dan oksitosin serta isapan bayi sangat diperlukan agar produksi ASI tetap ada walaupun sedikit[9].

Upaya merangsang produksi ASI dapat dilakukan dengan merangsang hormon prolaktin dan oksitosin diantaranya yaitu dengan menyusui dini (IMD), pijatan oksitosin diatas kulit, terutama pada bagian otot dengan gerakan mengurut, mengosongkan payudara untuk melancarkan oksigen dan membuat ibu rileks[14]. Upaya yang dapat dilakukan untuk meningkatkan produksi dan kelancaran ASI menggunakan teknik marmet dan kompres hangat. Teknik marmet merupakan kombinasi antara memerah ASI dan memijat payudara sehingga refleks keluarnya ASI lebih optimal[15]. Sedangkan kompres hangat adalah melakukan kompres dengan menggunakan handuk kecil atau waslap yang direndam pada suhu air hangat dengan suhu $34^{\circ} \mathrm{C}-37^{\circ} \mathrm{C}$ pada kedua payudara[16]. Teknik marmet dan kompres hangat tidak hanya berfungsi untuk meningkatkan dan melancarkan produksi ASI saja, namun teknik marmet dan kompres hangat juga bisa mengatasi pembengkakan payudara dan sumbatan aliran ASI.

Teknik marmet akan membuat payudara menjadi lebih lembut, mencegah puting dan aerola menjadi kering dan lecet, mengurangi pembengkakan pada payudara, refleks keluarnya ASI lebih mudah terstimulasi dengan Skin to skin contact karena ada proses memerah ASI dari areola hingga ke puting susu sehingga menyebabkan pengeluaran air susu lebih banyak dan dapat mengosongkan payudara yang penuh, meningkatkan hygiene payudara, membantu ibu secara phisiologis, nyaman dapat menangani 
stress, membangkitkan rasa percaya diri dan ibu dapat melakukannya sendiri[17].

Teknik marmet juga sangat efektif mengosongkan payudara sehingga produksi ASI meningkat dan aliran ASI menjadi lancar. Hal ini memudahkan bayi untuk mengisap, isapan bayi pada puting susu ibu akan merangsang ujung saraf sensoris disekitar payudara. Rangsangan ini disampaikan ke otak dan merangsang kelenjar hipofisis anterior untuk memproduksi hormon prolaktin.Hormon prolaktin merangsang sel-sel alveoli untuk memproduksi ASI. Sehingga dengan semakin seringnya bayi menyusu maka produksi ASI akan semakin banyak[18].

Kompres hangat pada payudara akan menstimulasi kulit dan jaringan di bawah payudara serta meningkatkan suhu payudara sehingga terjadinya vasodilatasi. Adanya vasodilatasi mengakibatkan peningkatan sirkulasi atau peredaran darah yang dapat menimbulkan relaksasi pada payudara, dapat meningkatkan aliran ASI, terstimulasinya refleks let down dan mencegah bendungan pada payudara. Refleks let down akanmempengaruhi kelenjar hipofisis posterior untuk melepaskan hormon oksitosin. Hormon oksitosin menyebabkan otot-otot kecil disekitar sel-sel penghasil susu berkontraksi dan mengeluarkan susu[19][16].

Teknik marmet dan kompres hangat dapat meningkatkan dan memperlancar produksi ASI yang sudah banyak di buktikan dalam penelitian terdahulu.Hasil penelitian Puspita, dkk (2019) tentang "Pengaruh Teknik Marmet Terhadap Kelancaran ASI Pada Ibu Postpartum". Dengan sampel berjumlah 30 ibu postpartum diperoleh nilai signifancy $=0,001$ ( $p$ value $<0,05$ ) yang berarti ada pengaruh teknik marmet terhadap kelancaran ASI pada ibu postpartum[10]. Sedangkan penelitian yang dilakukan oleh Hamidah (2016) yang berjudul "Pengaruh Teknik Marmet Terhadap Produksi ASI Pada lbu Postpartum Di RS PKU Muhammadiyah Gamping".Dengan sampel 40 responden hasil penelitian menunjukkan kelompok eksperimen dengan produksi ASI dengan kategori banyak sebesar $75.0 \% \quad(15$ responden), sedangkan kelompok kontrol responden dengan produksi ASI dengan kategori banyak sebesar 40.0\% (8 responden), diperoleh $p$-value $0,025<\alpha$ $0,05[20]$.

Penelitian lainnya yang dilakukan oleh Nurhamifah (2013) tentang "Perbedaan Efektifitas Massage Punggung Dan Kompres Hangat Payudara Terhadap Peningkatan Kelancaran Produksi ASI".Sampel dalam penelitian sebanyak 32 orang. Didapatkan hasil nilai signifikansi kurang dari á $=0,05$ $(0,002<0,05)$ sehingga dapat disimpulkan HO ditolak. Sehingga dapat disimpulkan bahwa pemberian kompres hangat payudara mampu meningkatkan kelancaran produksi ASI[12].

Penelitian yang dilakukan oleh Lulus, dkk (2016) tentang "Efektivitas Massage endorphine Dan Kompres Air Hangat Terhadap Kecukupan ASI Bayi Pada Ibu postpartum", dengan sampel 32 orang. Dapat disimpulkan bahwa ada pengaruh massage endorphine dan kompres air hangat terhadap kecukupan ASI bayi dengan indikasi berat badan bayi, frekuensi BAK, frekuensi menyusu, dan lama tidur setelah menyusu[21].

Hasil penelitian yang peneliti lakukan dengan melakukan kombinasi teknik marmet dan kompres hangat ternyata lebih efektif meningkatkan dan memperlancar produksi ASI dimana saat dua intervensi ini digabungkan akan terjadi dua reaksi sekaligus. Intervensi teknik marmet merupakan kombinasi antara cara memerah ASI dan memijat payudara secara manual dan mengutamakan let down reflex (LDR), sehingga pengosongan ASI dari sinus laktiferus yang terletak di bawah areola diharapkan akan merangsang pengeluaran hormon prolaktin yang diproduksi oleh kelenjar hipofisis anterior yang masuk ke dalam aliran darah ibu dan merangsang sel otot di sekeliling alveoli dan merangsang mammary alveoli[15]. Alveoliberkontraksi 
sehingga dengan pijatan di daerah payudara akan memberikan rasa nyaman dan releksasi, menghilangkan stress, payudara lunak dan mengosong dengan begitu hormon prolaktin keluar dan akan membantu memproduksi ASI dan juga mengaktifkan kembali reflek keluarnya air susu atau milk ejection refleks (MER) sehingga air susu mulai menetes[17][22]

Kombinasi teknik marmet dan kompres hangat akan meningkatkan produksi ASI lebih banyak, yang mana setelah teknik marmet selesai dilanjutkkan dengan intervensi kompres hangat yang menstimulasi kulit dan jaringan di bawah payudara dengan menggunakan aplikasi panas yang akan memberikan sinyal ke hipotalamus melalui sumsum tulang belakang, sistem efektor mengeluarkan

\section{SIMPULAN}

Berdasarkan penelitian yang dilakukan tentang "Pengaruh Kombinasi Teknik Marmet dan Kompres Hangat Terhadap Produksi ASI Pada lbu Postpartum Di PMB Dince Safrina Kota Pekanbaru", hasil penelitian didapatkan kesimpulan bahwa ada pengaruh teknik marmet dengan dan tanpa kompres hangat terhadap produksi ASI pada ibu postpartum $(p=0,015)$ yaitu kombinasi teknik marmet dan kompres hangat lebih efektif meningkatkan produksi ASI.

\section{UCAPAN TERIMA KASIH}

a. Tempat Penelitian

Diharapkan kepada tenaga kesehatan khususnya di PMB Dince Safrina agar dapat menerapkan kombinasi teknik marmet dan kompres hangat sebagai alternatif metode non farmakologi untuk meningkatkan dan memperlancar produksi ASI.

b. Institusi Pendidikan

Diharapkan bagi institusi pendidikan penelitian ini dapat dikembangkan dan dijadikan untuk memperkaya bahan pembelajaran jurusan kebidanan tentang kombinasi teknik marmet dan kompres hangat sebagai metode non farmakologi sinyal dengan vasodilatasi perifer[23]. Adanya vasodilatasi mengakibatkan peningkatan sirkulasi atau peredaran darah yang dapat menstimulasi reflex let down atau refleks pengaliran ASI dilepaskan kedalam aliran darah oleh kelenjar hipofisis posterior untuk melepaskan hormon oksitosin. Hormon oksitosin menyebabkan otot-otot kecil disekitar sel-sel penghasil susu berkontraksi dan mengeluarkan susu. Hormon oksitosin juga menyebabkan duktus melebar dan memendek sehingga air susu mengalir keluar untuk meningkatkan aliran ASI, kompres hangat juga menimbulkan rasa nyaman dan relaksasi pada payudara, kombinasi teknik marmet dan komprres hangat terbukti dapat meningkatkan produksi ASI[16].

untuk meningkatkan dan memperlancar produksi ASI.

Bagi mahasiswa dalam praktik klinik dapat menerapkan kombinasi teknik marmet dan kompres hangat sebagai salah satu asuhan dalam meningkatkan dan memperancar produksi ASI.

\section{c. Peneliti Lain}

Diharapkan penelitian ini dapat dijadikan informasi awal untuk penelitian selanjutnya untuk melakukan penelitian serupa atau mengkombinasikannya dengan metode non farmakologi yang lainnya dengan sampel yang lebih besar sehingga didapatkan hasil yang lebih akurat.

\section{DAFTAR PUSTAKA}

[1] IDAl, Air Susu Ibu Dan Pengendalian Infeksi. diakses pada tanggal 24 Oktober 2019., 2013.

[2] M. Pollard, ASI Asuhan Berbasis Bukti. Jakarta: EGC, 2016.

[3] WHO (World Health Organization), Cakupan ASI Eksklusif Di Seluruh Dunia. Geneva: WHO., 2016.

[4] I. B. F. A. N. (IBFAN), Pekan ASI Sedunia $2018 . \mid \mathrm{BI}, 2014$.

[5] profil kesehatan indonesia, Provil 
Kesehatan Indonesia 2018, vol. 1063, no. May. 2018.

[6] D. K. Pekanbaru, "Profil Kesehatan Kota Pekanbaru Tahun 2016," J. Chem. Inf. Model., vol. 53, no. 9, p. 287, 2008.

[7] G. Joko, Buku Saku Metodologi Penelitian Kesehatan.Sulawesi Tenggara CV. Violet Indah Sejahtera., 2017.

[8] A. . Susanto, Nifas Dan Menyusui. Yogyakarta: Nuha Medika, 2018.

[9] R. P.A, Keperawatan Maternitas. Yogyakarta: Deepblish, 2016.

[10] L. Puspita, M. Y. Umar, and P. K. Wardani, "Pengaruh Teknik Marmet Terhadap Kelancaran Asi Pada lbu Post Partum," vol. 1, no. February, pp. 87-92, 2019.

[11] A. K. Dahlan, "Pengaruh Teknik Marmet Terhadap Kelancaran ASI Pada Ibu Menyusui," vol. 07, no. 09, pp. 91-96, 2017.

[12] Nurhanifah Fitrah, "Perbedaan Efektifitas Massage Punggung Dan Kompres Hangat Payudara Terhadap Peningkatan Kelancaran Produksi Asi Di Desa Majang Tengah Wilayah Kerja Puskesmas Pamotann Dampit Malang," J. Keperawatan, pp. 100-108, 2013.

[13] E. R. Suryani Manurung, Ani Nuraini, Tri Riana, li Soleha, Heni Nurhaeni, Khaterina Pulina, "Pengaruh Tehnik Pemberian Kompres Hangat Terhadap Perubahan Skala Nyeri Persalinan Pada Klien Primigravida," J. Heal. Qual., vol. 4, no. 1, pp. 1-76, 2013.

[14] Paryono, "Oxytocin Massage Training in Family Mother Postpartum In General Hospital Center dr. Soeradji Tirtonegoro Klaten," p. 400, 316 AD.

[15] Mas'adah and Rusmini, "Teknik Melancarkan Asi Pada lbu Post Sectio Caesaria," J. Kesehat. Prima, vol. 9, no. 2, pp. 1495-1505, 2015.
[16] S. dan R. D.P, Perawatan Payudara. Yokyakarta: Mitra Cendikia Press, 2009.

[17] Y. Aprilia, Hipnostetri: Rileks, Nyaman, dan Aman Saat Hamil \& Melahirkan. Jakarta: Gagas Media, 2010.

[18] U. Roesli, Panduan Inisiasi Menyusu Dini Plus Asi Eksklusif. Jakarta: Pustaka Bunda, 2012.

[19] P. Simkin, Kehamilan Melahirkan Dan Bayi. Jakarta: Arcan, 2008.

[20] K. Hadimah, "Pengaruh teknik marmet terhadap produksi asi pada ibu post partum di rumah sakit pku muhammadiyah gamping," pp. 118, 2016.

[21] M. and S. Lulus Nauri, "Efektivitas Massage Endorphine Dan Kompres Air Hangat," pp. 1-7.

[22] A. Widiastuti and S. Arifah, "Pengaruh Teknik Marmet dengan Masase Payudara pada lbu Nifas Tiga Hari Post Partum Terhadap Kelancaran ASI dan kenaikan BB Bayi," Ris. Kesehat., vol. 4, no. 3, pp. 826-831, 2015.

[23] G. Bulechek, Nursing Interventions Classification. . United Kingdom: Elservier, 2013. 